\title{
Effect of Spacing and Poultry Manure Rates on Growth, Yield and Quality of Cayenne Pepper (Capsicum frutescens. L) in Southern Rain Forest of Nigeria
}

\author{
Ansa J.E.O.*1 and Woke C. ${ }^{2}$ \\ ${ }^{1}$ Department of Agriculture, Ignatius Ajuru University of Education, \\ (Ndele Campus), Port Harcourt, Rivers State, Nigeria \\ Email: joseph.ansa@iaue.edu.ng \\ ${ }^{2}$ Department of Agricultural Technology, Captain Elechi Amadi Polytechnic, Port Harcourt, Rivers State, Nigeria
}

\begin{abstract}
Field experiment was conducted at the Teaching and Research Farm of the Department of Agriculture, Ndele Campus, Ignatius Ajuru University of Education, Port Harcourt, Rivers State, to study the effects of poultry manure rates and crop spacing on growth, yield and quality of Cayenne pepper. The $3 \times 3$ factorial experiment with three replicates was arranged in a Completely Randomized Design. The main plots were three poultry manure rates $(0$, 10, 20tons/ha-1) and sub plots, three spacing $(50 \mathrm{~cm} \times 50 \mathrm{~cm}$, $100 \mathrm{~cm} \times 50 \mathrm{~cm}$ and $100 \mathrm{~cm} \times 100 \mathrm{~cm})$. Data collected were plant height, number of leaf per plant, leaf area; number of fruits per plot, fruit weight per plot, fruit yield per hectare, fruit lycopene and vitamin C contents. Results showed plant height increased with reducing planting distance and increasing Poultry manure rate; $50 \mathrm{~cm}$ by $50 \mathrm{~cm}$ fertilized at 20tons/ha produced the tallest plants with most number of leaves but least leaf area LA. Number of fruits, fruit weight and yield per plot, per hectare increased with increasing planting density and increasing Poultry manure rates lycopene and vitamin c contents increased with Poultry manure levels within the different spacing. Spacing of $50 \mathrm{~cm}$ by $50 \mathrm{~cm}$ fertilized with poultry manure at 20 tons per hectare is recommended.
\end{abstract}

Keywords-Cayenne pepper, Poultry Manure, Rainforest, Spacing, Yield.

\section{INTRODUCTION}

Cayenne pepper, Capsicum frutescens, a member of hot pepper Solanaceous family, thought to be native of South America, is commonly used as ingredient in the preparation of soups, sauces, stew probably because it contain s essential nutrients and vitamins such as A, E and C. It is called "sombo" and produced in Nigeria where it is consumed by the people fresh, dried or processed $[1,2,3]$. The land area under pepper production in Nigeria as at 1988 and increasing was estimated to be $100-200$ hectares [4]. Factors accounting for this increasing land under Capsicum production on the one hand, is its consumption in Nigeria which accounts for 40 percent of the total vegetable consumed per day and on the other hand the lucrative export business. Nigerian pepper is in high demand abroad because of its pungency and good flavor and it can be readily dried, ground and packaged for export [5].

Although pepper can be grown all over Nigeria, the northern region between latitude $10^{\circ} \mathrm{N}$ and $12^{\circ} \mathrm{N}$ is the major area for production where an estimated 77,000 hectares of land under pepper cultivation yields about 695000 metric tons [6]. The export attraction has encouraged pepper production in western Nigeria where production have been accompanied with a lot of research $[1,2,7]$ and in the eastern region that even has special indigenous variety, "Nsukka yellow pepper" [8, 9]. Literature is scarce for Capsicum spp. production in the southern rainforest region of Nigeria.

Capsicum yield among peasant farmers are often very low [10]. In general Capsicum yield in the developing countries is comparatively lower than those of the developed countries in the region of about $10-30 \%$ less.

Reduced and inherent soil fertility and management practices, weeds infestation and diseases problems have been largely attributed to the lower yields [3, 5]. Crop intensification, higher planting densities, judicious use of fertilizers and organic matter maintenance have been proffered as panacea for improved production output of tropical crop production [11, 12]. The southern rainforest of 
Nigeria, a typical rainforest is characterized by high rainfall amounts and intensity that has been credited with high leaching that has resulted in impoverishing of the soil making it fragile [13]. Therefore, fertilization studies on pepper production in this region become imperative.

Organic manure application has been reported to be more beneficial over the use of chemical fertilization in tropical crop production, sustainability and soil fertility management. The addition of organic manure enhances crop yield because of improved soil productivity as a result of increased soil organic carbon content and improved soil physical, soil chemical and soil biological properties [6, 14]. Whereas the use of chemical fertilizers supply mainly one or a few macronutrients, in addition to their ruinous effect to the soil, organic fertilization conditions the soil, supplies several macro and micro nutrients, improves and maintain soil fertility status and also improves crop response to inorganic fertilization $[15,16]$. The use of organic fertilizer has been reported to improve flavor and quality of vegetable crops as against the use of inorganic fertilizer. Inorganic fertilization dis-flavored the 'Nsukka yellow' pepper while organic manure enhanced flavor and opined the best option in the cultivation of the pepper [17]. Amaranth plants with organic manure treatment had higher nutritional values in the entire plant (leaf, stem, inflorescence and root) than those with inorganic fertilizer treatment [18]. The above informed the researchers on the study of organic fertilization instead of inorganic fertilization. Poultry manure among other sources of organic manure was selected because it is superior and has higher nutrient content than other sources at the farmer's disposal [19, 20, 21].

Increasing the number of crops per unit farmland is one of recommendations for increased yield or crop produce output. Yield increase as a result of closely spaced crops (i.e. higher density) in a crop like pepper is because more plants will produce more fruits, hence increase in number of fruits or yield [22]. Increasing the planting density of bell pepper resulted in higher yield (kg.ha-1) [23]. Southern Nigeria tropical rainforest is characterized by high rainfall amounts with wide monthly variation, intensification in terms of high planting density might favor high yield in cayenne pepper production.

The study was therefore undertaken to assess the effect of spacing and poultry manure rates on the growth, yield and fruit quality of Capsicum frutescens in the southern Rainforest of Nigeria.

\section{MATERIALS AND METHODS}

Study Site

The experiment was conducted at the Teaching and Research Farm of the department of Agriculture, Ignatius Ajuru University of Education, Ndele Campus, Port Harcourt, River state, between July and November, 2017. Ndele is located in the southern rainforest region with about 9.5 months of adequate rainfall, 2.5 dry season months, and cumulative insolation of $120-160 \mathrm{Kcal} / \mathrm{cum}$ per annum [24].

\section{Nursery practice}

Seeds of cayenne pepper variety of Capsicum frutescens were on enclosed $1 \mathrm{~m}$ x $1 \mathrm{~m}$ nursery beds made of dark top soil. The beds were watered before the seeds were broadcasted evenly and watered. After emergence, thinning was done, removing some seedlings so that strong healthy pepper seedling can be obtained for transplanting. Seedlings were watered daily and ready for transplant after 40 days.

\section{Land Preparation}

The total experimental area was manually cleared, grass stumps dug out. The soil was tilled with spade and $3 \mathrm{~m}$ by 3 $\mathrm{m}$ beds were constructed. The individual beds were then mapped out according to the respective spacing ready for seedling transplant.

\section{Experimental Design/Treatment}

The study adopted a $3 \times 3$ factorial experiment arranged in a randomized complete block design (RCBD) and replicated three times. The treatments were (i) Poultry manure rates $(0$, 10 and 20 tons per hectare) and (ii) Spacing $(50 \mathrm{~cm} \times 50 \mathrm{~cm}$; $100 \mathrm{~cm} \times 50 \mathrm{~cm}$ and $100 \mathrm{~cm} \times 100 \mathrm{~cm})$. Poultry manure rates were the main plots while spacing the sub plots, replicated 3 times to give a total of 9 main plots and 27 sub plots. Treatment combinations were randomly allotted to plots. Application of poultry manure was done 2 weeks after transplanting. Soil sample of the experimental sight were obtained using soil auger ad sent to the Laboratory for analysis.

\section{Data collection and analysis}

Vegetative and growth parameters measured at 2, 4 6, 8 and 10 weeks after transplanting were plant height (growth rate), number of leaves and leaf area.

Yield parameters determined at harvest were number of fruits per plot, fruit weight per plot and estimated fruit yield per hectare.

Fruit quality were accessed by determining fruit moisture and Vitamin C contents [25] and lycopene content [26].

Data collected were subjected to analysis of variance and means separated by Duncan Multiple Rang Test (DMRT) using PASW $18^{\text {th }}$ Edition statistical software. 


\section{Visual Observation}

\section{RESULTS}

It was observed that application of poultry manure irrespective of the spacing resulted in darker green leaves of the pepper. Application of the manure also enhanced the establishment of the transplanted seedling.

\section{Growth Response}

Growth response (plant height) of cayenne pepper to varying rate of poultry manure and spacing is displayed in Table 1. Irrespective of treatments, plant height i.e. growth rate increased with age of the plants. Also, plant height increased with density i.e. spacing. The growth rate response to spacing was significant $(\mathrm{P} \leq 0.05)$, indicating that the variation in plant height was due to the different spacing. The trend was that plant height increased as the distance (spacing) between plants reduced. At 10 weeks after transplanting (WAT) cayenne plants spaced at $50 \mathrm{~cm} \times 50$ $\mathrm{cm}$ were 1.5 times taller than the most widely spaced plant at $100 \mathrm{~cm} \mathrm{x100} \mathrm{cm.}$

Application of poultry manure rates was also responsible for the variation in plant height (Significant Fcal $\mathrm{P}<0.05$ ). Increasing rates of poultry manure resulted in positive correlating increase in plant height of cayenne plants. While the difference in height between the control plants and those that received poultry manure was not significant at 2 WAT, it became significant by $10 \mathrm{WAT}$, the difference in height was $40 \%$ over the control plants.

\section{Vegetative Growth}

The influence of spacing and poultry manure on vegetative characteristics of cayenne pepper is highlighted in Table 2. Cayenne pepper spaced at $100 \mathrm{~cm}$ by $100 \mathrm{~cm}$ had plants with the least number of leaves, and significantly different from those spaced at $50 \mathrm{~cm}$ by $50 \mathrm{~cm}$ and $100 \mathrm{~cm}$ x $50 \mathrm{~cm}$ ( $\mathrm{P}<0.05)$. Though, pepper plant spaced at $50 \mathrm{~cm}$ by $50 \mathrm{~cm}$ had higher number of leaves than those spaced at $100 \mathrm{~cm} \mathrm{x}$ $50 \mathrm{~cm}$, the difference was not statistically or markedly different.
Poultry fertilizer rate had marked statistically significant effect on number of leaves of cayenne pepper. Number of leaves increased significantly with increase rates of poultry manure application. Plants that were fertilized with 20ton/ha PM rate recorded the highest number of leaves (14) compared to with the control plants.

There were marked variation in cayenne pepper leaf area due to the various spacing (Table 2). Pepper crops spaced 50 $\mathrm{cm}$ by $50 \mathrm{~cm}$ had the smallest size of leaves (less leaf area), while those spaced and $100 \mathrm{~cm}$ x $50 \mathrm{~cm}$ and $100 \mathrm{~cm}$ by 100 $\mathrm{cm}$ were not significantly different but produced leaves with higher leaf area than those spaced at $50 \mathrm{~cm} \times 50 \mathrm{~cm}$.

Poultry manure doses had marked leaf area variation in Capsicum frutescens. The Pepper crops that did not receive poultry manure had the smallest sized leaves (leaf area). Increasing levels of poultry manure resulted in increasing sizes of leaves. Cayenne pepper plant that received 20 ton/ha poultry manure application produced the highest leaf area of $56.8 \mathrm{~cm}^{2}$. This is followed by plants that received 10 ton/ha which produced leaf area of $53.9 \mathrm{~cm}^{2}$.

\section{Fruit Yield}

The effect of spacing and poultry manure rate on cayenne pepper fruit yield is shown on Table 3. Number of harvested fruit and fruit weight (yield) were markedly affected by spacing. Fruit yield and numbers increased with the closer high density spacing. Thus plants spaced $50 \mathrm{~cm} \times 50 \mathrm{~cm}$ had doubled the yield of those spaced at $100 \mathrm{~cm}$ by $100 \mathrm{~cm}$ and was the yield per plot was 3 times over those spaced at 100 $\mathrm{cm} \times 100 \mathrm{~cm}$.

The response of Capsicum frutescens to poultry manure inclusion was such that fruit yield per plot and per hectare increased with increasing levels of the manure. The yield of the crop at application rates of 10 and 20 ton/ha was not significantly different. However there was marked difference in yield between poultry manure fertilized pepper crop and the control. The increase in yield of 10 and 20 ton/ha fertilized pepper plants over the control plants was $65 \%$ and $83 \%$ respectively.

Table.1: Effect of Spacing and Poultry Manure rates on Capsicum frutescens growth rate (Plant height cm)

\begin{tabular}{llllll}
\hline Spacing & \multicolumn{5}{c}{ Weeks after Transplanting } \\
& 2 & 4 & 6 & 8 & 10 \\
\hline $50 \mathrm{~cm}$ x $50 \mathrm{~cm}$ & $17.0^{\mathrm{c}}$ & $19.3^{\mathrm{c}}$ & $27.3^{\mathrm{c}}$ & $34.1^{\mathrm{c}}$ & $39.5^{\mathrm{c}}$ \\
$100 \mathrm{~cm} \times 50 \mathrm{~cm}$ & $16.3^{\mathrm{b}}$ & $17.7^{\mathrm{b}}$ & $24.3^{\mathrm{b}}$ & $28.4^{\mathrm{b}}$ & $32.1^{\mathrm{b}}$ \\
$100 \mathrm{~cm} \times 100 \mathrm{~cm}$ & $12.4^{\mathrm{a}}$ & $14.4^{\mathrm{a}}$ & $18.4^{\mathrm{a}}$ & $24.3^{\mathrm{a}}$ & $26.1^{\mathrm{a}}$ \\
$\mathrm{SE}$ & .186 & .173 & .366 & .529 & 1.020 \\
Poultry Manure $(\mathbf{P M})$ Rate & $14.5^{\mathrm{a}}$ & $16.5^{\mathrm{a}}$ & $21.4^{\mathrm{a}}$ & $25.5^{\mathrm{a}}$ & $26.2^{\mathrm{a}}$ \\
0 & $15.2^{\mathrm{a}}$ & $16.9^{\mathrm{a}}$ & $23.8^{\mathrm{b}}$ & $29.9^{\mathrm{b}}$ & $34.4^{\mathrm{b}}$ \\
$10 \mathrm{ton} / \mathrm{ha}$ & $16.0^{\mathrm{a}}$ & $18.0^{\mathrm{b}}$ & $24.9^{\mathrm{c}}$ & $31.4^{\mathrm{c}}$ & $36.9^{\mathrm{b}}$ \\
20 ton/ha & &
\end{tabular}




\begin{tabular}{llllll}
$\mathrm{SE} \pm$ & .186 & .173 & .366 & .529 & 1.020 \\
Spacing X PM Rate & $\mathrm{NS}$ & $*$ & $*$ & $*$ & $*$ \\
\hline
\end{tabular}

Means followed by same letter in each column are not significantly different at $P<05$ by Duncan multiple rage test. * $=$ Significant. NS = Not significant.

Table.2: Influence of spacing and poultry manure rate on vegetative characteristics of Capsicum frutescens (10 WAT)

\begin{tabular}{lll}
\hline Spacing & No. of Leaves & LA $\left(\mathbf{c m}^{3}\right)$ \\
& & \\
\hline $50 \mathrm{~cm} \times 50 \mathrm{~cm}$ & $13.8^{\mathrm{b}}$ & $42.3^{\mathrm{a}}$ \\
$100 \mathrm{~cm} \times 50 \mathrm{~cm}$ & $13.3^{\mathrm{b}}$ & $47.4^{\mathrm{b}}$ \\
$100 \mathrm{~cm} \times 100 \mathrm{~cm}$ & $12.0^{\mathrm{a}}$ & $47.4^{\mathrm{b}}$ \\
SE & .203 & .272 \\
Poultry Manure (PM) Rate & & \\
0 ton/ha & $11.2^{\mathrm{a}}$ & $24.5^{\mathrm{a}}$ \\
10 ton/ha & $13.4^{\mathrm{b}}$ & $53.9^{\mathrm{b}}$ \\
20 ton/ha & $14.4^{\mathrm{c}}$ & $56.8^{\mathrm{c}}$ \\
SE & .203 & .272 \\
Spacing \& PM Rate & $\mathrm{NS}$ & $\mathrm{NS}$ \\
\hline
\end{tabular}

* Means followed by same letter in each column are not significantly different at $P<05$ by Duncan multiple rage test $*$.

Table.3: Effect of Spacing and Poultry manure levels on yield in Capsicum frutescens

\begin{tabular}{lccc}
\hline Spacing & Number of Fruit & Fruit weight/plant $(\mathbf{g})$ & Fruit yield kg/ha \\
\hline $50 \mathrm{~cm}$ x $50 \mathrm{~cm}$ & $192.4^{\mathrm{a}}$ & $456.7 \mathrm{a}$ & 507.4 \\
$100 \mathrm{~cm} \times 50 \mathrm{~cm}$ & $111.2^{\mathrm{b}}$ & $265.2 \mathrm{~b}$ & 294.6 \\
$100 \mathrm{~cm} \times 50 \mathrm{~cm}$ & $61.7^{\mathrm{c}}$ & $148.9 \mathrm{c}$ & 165.4 \\
S.E. & 1.478 & 4.147 & \\
Poultry Manure $(\mathbf{P M})$ & Rate & & \\
0 ton/ha & $83.8^{\mathrm{a}}$ & $194.2^{\mathrm{a}}$ & 215.7 \\
10 ton/ha & $133.5^{\mathrm{b}}$ & $321.5^{\mathrm{b}}$ & 357.2 \\
20 ton/ha & $148.0^{\mathrm{c}}$ & $355.0^{\mathrm{b}}$ & 394.4 \\
S.E. & 1.478 & 4.147 & \\
\hline
\end{tabular}

* Means followed by same letter in each column are not significantly different at $P<0.05$ by Duncan multiple rage test $*$.

Table 4 shows the quality effects to spacing and poultry manure levels by cayenne pepper. Per cent moisture content was not influence by spacing and poultry manure rates as no clear trend was observed. However the widely spaced crops at $100 \mathrm{~cm}$ by $100 \mathrm{~cm}$ had more moisture in the fruit. Within each spacing treatment vitamin contents in the fruits increased with manure rates, with plants spaced at $50 \mathrm{~cm} \mathrm{x}$ $50 \mathrm{~cm}$ producing pepper plants with highest vitamin $\mathrm{c}$ as manure level increase.

Lycopene content in cayenne fruit were positively affected by poultry manure in all spacing treatment. Plants that did not receive manure had lowest levels of lycopene; however among the plants that were spread at $100 \mathrm{~cm}$ by $50 \mathrm{~cm}$ lycopene content of the control plants had higher lycopene levels than those fertilized with poultry manure.

In plant spaced at $100 \mathrm{~cm}$ by $100 \mathrm{~cm}$, increasing poultry manure rate beyond 10 ton/ha resulted in reduction of lycopene content in the fruit. In plants spaced at $50 \mathrm{~cm}$ by 50 $\mathrm{cm}$ increasing poultry manure content resulted in increasing levels of lycopene in fruit. 
Table.4: Influence of spacing and poultry manure rates on fruits quality cayenne pepper

\begin{tabular}{ccccc}
\hline Spacing & $\begin{array}{c}\text { Poultry manure rate } \\
\text { Ton/ha }\end{array}$ & $\begin{array}{c}\text { \% Moisture } \\
\text { Content }\end{array}$ & Vitamin C & $\begin{array}{c}\text { Lycopene } \\
\text { (mg/kg) }\end{array}$ \\
\hline $50 \mathrm{~cm} \times 50 \mathrm{~cm}$ & 0 & 77.77 & 0.26 & 28.50 \\
& 10 & 74.43 & 0.61 & 31.12 \\
& 20 & 75.74 & 0.77 & 34.45 \\
$100 \mathrm{~cm} \times 50 \mathrm{~cm}$ & 0 & & & \\
& 10 & 79.43 & 0.26 & 28.50 \\
& 20 & 73.27 & 0.3562 & 17.95 \\
& & & 0.4272 & 24.89 \\
$100 \mathrm{~cm} \times 100 \mathrm{~cm}$ & 0 & 79.87 & & \\
& 10 & 70.2 & 0.26 & 28.51 \\
& 20 & 75.4 & 0.2637 & 60.19 \\
& & & & 49.65 \\
\hline
\end{tabular}

\section{DISCUSSION}

Fffect of Spacing and Poultry Manure Rates on Growth and Yield of Cayenne Pepper

This study observed that plant height, that is, growth rate increased with spacing. This is in line with studies by other researchers who reported increase in plant height in closely spaced green pepper in Kenya [27]. It was also observed that increasing the rate of poultry manure led to increasing plant height of cayenne pepper. This observation corroborates other research findings on aromatic pepper, Capsicum annum L var (Nsukka yellow) in Nsukka, Enugu State, Nigeria [28]; that plant height increased with increasing poultry manure rates.

Reducing planting distance and increasing poultry manure rate resulted in increasing number of leaves. This is similar to the reports increasing vegetative growth with poultry manure application in Nsukka yellow anomatic pepper at Nsukka [29].

The fruit yield of cayenne pepper increased with spacing per plot and per hectare. This could be as a result of higher population of plants, with each individual plants producing high number of fruits. Similarly in a different study on green pepper, closely spaced pepper recorded higher yields than widely spaced pepper [27]; while higher yield was observe in tomatoes with increasing levels of poultry manure [30].

Effect of Spacing and Poultry Manure on fruit quality of Cayenne pepper

Increasing levels of poultry manure resulted on the increasing contents of lycopenes and Vitamin $\mathrm{C}$ in this study. This finding is similar to the findings of other research done on tomato; which indicated that lycopene content increased with poultry manure levels [30]. However their findings [30] that control tomatoes plant had higher vitamin content than those receiving poultry manure is contrary the observation in this study. It was observed that the control plants had lower levels of Vitamin C compared with cayenne pepper that received poultry manure.

\section{CONCLUSION}

Spacing cayenne pepper at $50 \mathrm{~cm}$ by $50 \mathrm{~cm}$ will result in higher growth rate and yield. Application of 20 ton/ha of poultry manure will result in higher growth rate and yield. Spacing has no significant difference on lycopene and vitamin content in cayenne pepper. Increasing rate of poultry manure results in higher Vitamin $\mathrm{C}$ content in cayenne pepper. Application of 20 ton/ha poultry manure and a spacing of $50 \mathrm{~cm}$ by $50 \mathrm{~cm}$ is recommended for cayenne pepper production in the southern rainforest zone of Nigeria.

\section{REFERENCES}

[1] Alegbejo, M.F., Orakwe, F.C. \& Ado, S.G. (1999). Characteristics of chilli pepper cultivars released by the Institute for Agricultural Research, Samaru, Nigeria. Capsicum and eggplant Newsletter,18, 21-24.

[2] Denton O.A., Olufolaji A.O. (2000). Nigeria's most important vegetable crops. In: Akoroda, M.O. (Compiler). Agronomy in Nigeria: A Book in Support of Agronomy Re-Union Day on 4th October 2000. Department of Agronomy, University of Ibadan, Nigeria 85-93.

[3] Grubben, G.J.H., \& El-Tahir, I.M. (2004). Capsicum annum L. In: (Grubben, G.J.H. and Denton, O.A, Editors). Plant Resources of Tropical Africa 2. Vegetables. (pp.154-163). PROTA Foundation, Wageningen, Netherlands/CTA Wageningen, Netherlands. 
[4] Ado, S.G. (1988). Evaluation of Capsicum in Nigeria. PGR Capsicum Eggplant Newslett., 17: 16-17.

[5] Erinle, I.D. (1989). Present status and prospects for increased production of tomato and pepper in Northern Nigeria. Tomato and pepper in the tropics AVRDC Shauhua Taiwan. p 545.

[6] FAO. (2000). Fertilizers and their Use. 4th Edn., Food and Agriculture Organization, Rome, Pages: 34.

[7] Alabi, D.A. (2006). Effect of fertilizer phosphorus and poultry droppings treatments on growth and nutrient components of pepper Capsicum annum. African Journal of Biotechnology, 5 (8): 671-677.

[8] Ajayi AR and Eneje CN (1998). Preference of Nsukka Yellow Pepper Among Growers and Consumers in Nsukka agricultural zone of Enugu State,Nigeria. Proc. 15th HORTISON conf., Ibadan, 8th - 11th April. pp. 184-187.

[9] Echezona, B.C and Nganwuchu, O.G. (2006). Poultry Manure application and varietal effects of chillipepper (Capsicum spp.) on insect pest and disease in a humid -tropical environment. Journal of Agriculture, Food, Environment and Extension 5 (2): 49-58.

[10] Adigun, J.A. (2001). Influence of intra-row spacing and chemical weed control on the growth and yield of chilli pepper (Capsicum frutescens L.) in the Nigerian Northern Guinea Savannah. Nigerian Journal of Horticultural Science 5:67-73.

[11] Agboola, A.A., (1982). Organic manuring and green manuring in Tropical Agricultural systems. Proc. of 12 Inter. Cong. of Soil Science, New Delhi, India 8-16 February, pp: 198.

[12] Hamma, I.L. and Ibrahim, U. (2013). Management Practices for Improving Fertility Status of Soils in Nigeria. World Journal of Agricultural Sciences 9 (3): 214-219.

[13] Elliott, S.D., Blakesley, D. and Hardwick, K. (2013). Restoring Tropical Forests: a practical guide. Royal Botanic Gardens, Kew; 344 pp.

[14] Udoh, D. J., Ndon, B. A., Asuquo, P. E. and Ndaeyo, N. U. (2005). Crop Production Techniques for the Tropics. Concept Publication Lagos. Pp.446.

[15] Mahmoud A. M and Soliman A .Sh (2017). Comparative Study on the Influence of Organic Fertilizer and Soil Amendments on Evening Primrose (Oenothera biennis L.). International Journal of Agricultural Research, 12: 52-63.

[16] Akande, M. O., Kayode, C. O., Oluwatoyinbo, F. I. and Adediran, J. A. (2008). Efficiency of NEB-33 fortified fertilizers on growth and yield of pepper
(Capsicum frutescens). African Journal of Biotechnology, 7 (7): 873-877.

[17] Onugha AI (1999). Growth and yield response of Nsukka yellow pepper, Capsicum annuum, to plant population and levels of organic manure application, B. Agric. Project report, Dept. of Crop Science, University of Nigeria, Nsukka, Nigeria $43 \mathrm{p}$.

[18] Mofunanya, A.A.J., Ebigwai, J.K., Bello O.S. and Egbe A.O.(2015). Comparative Study of the Effects of Organic and Inorganic Fertilizer on Nutritional Composition of Amaranthus spinosus L. Asian Journal of Plant Sciences 14 (1): 34-39.

[19] Ikeh A.O. Ndaeyo N.U, Uduak I.G. Iwo G.A. Ugbe L.A, Udoh E.I. Effiong G.S. (2012). Growth and yield responses of pepper (Capsicum frutescens $\mathrm{L}$ ) to varied poultry manure rates in Uyo, Southeastern Nigeria, ARPN Journal of Agricultural and Biological Science; 7(9): 735-742.

[20] Asiegbu, J.E. (1987). Effect of organic matter substrate sources and time of photosynthetic-sink removal on Flower and Pod Production I Okra Abelmoschus esculentus (L) Moench. East Afr. Agric. Forest. J., 52, $293-297$.

[21] De Lannoy, G. and Romain, H. R. (2001). Crop Production in Tropical Africa. McGraw Hill Publishers Ltd. New York Pages 245

[22] Cavero, J., Ortega Gil, R., and Gutierrez, M. (2001). Plant density affects yield, yield components and color of direct-seeded paprika pepper. HortScience 36(1), 7679 .

[23] Nasto T. H., Balliu A. and Zeka N. (2009). The influence of planting density on growth characteristics and fruit yield of peppers (Capsicum annuum). Acta Hort. 830 906-912.

[24] Ansa, J. E. O. (2016). Effect groundnut spacing on yield and weed control in the rainforest agro-ecological zone of Nigeria. Direct Research Journal of Agriculture and Food Science. Vol. 4 (12): 49-52.

[25] AOAC (2005). Association of Official Analytical Chemist (AOAC), Official methods of analysis, 6th ed., Washing-ton DC, USA, 1980.

[26] Suwanaruang, T. (2016). Analyzing lycopene Content in Fruits. (International Conference on Inventions \& Innovations for Sustainable Agriculture 2016, ICIISA), Agriculture and Agricultural Science Procedia 11: 46 48.

[27] Edgar, O. N., Gweyi-Onyango J. P. and Korir N.K. (2017). Plant Row Spacing Effect on Growth and Yield of Green Pepper (Capsicum annuиm L.) in Western 
Kenya. Archives of Current Research International 7(3):

1-9.

[28] Baiyeri, P. K., Otitoju, G. T., Abu, N. E., and Umeh, S. (2016). Poultry manure influenced growth, yield and nutritional quality of containerized aromatic pepper (Capsicum annuum L., var 'Nsukka Yellow'). African Journal of Agricultural Research. Vol. 11(23): 20132023.

[29] Abu, N. E., and Odo, C. V. (2017). The effect of plant density on growth and yield of 'Nsukka Yellow' aromatic pepper (Capsicum annuum L.). African Journal of Agricultural Research. Vol. 12(15), pp. 1269-1277.

[30] Adeniyi, H. and Ademoyegum, O. (2012). Effect of different rates and sources of fertilizers on yield and antioxidant components of Tomato. Agric J 7 : $135-138$. 